contain diseases, such as take-all, lodging diseases and others, and the crop suffers more heavily.

The effects of temporary leys, green manures, and fallows as preparation for wheat are also under investigation, and the field trials are combined with work in the chemistry department to follow seasonal changes in nitrates, ammonia, and readily decomposed crop residues in the soil ; an attempt is made to trace the form in which available nitrogen is carried over from one year to another.

Sugar beet is the subject of extensive investigations carried out on a variety of soils, in conjunction with the sugar factories; the extent of these experiments may be judged from the fact that, in 1938, there were 38 experiments, with 1,360 plots. These experiments are mainly concerned with manurial responses in the various soil groups. The year 1938 was disappointing as regards this crop, the yield, expressed in terms of sugar, having been $12.5 \mathrm{cwt}$. per acre less than the average of the previous four years.
Other long-term experiments recorded are those on organic manuring by means of green crops, town refuse and straw. The question of organic manuring, and of the use of town refuse in particular, is of more than ordinary interest to-day. It is interesting to note that a prepared town refuse gave encouraging results in a comparison with sulphate of ammonia, dung and rape dust. The refuse gave rather higher yields than farmyard manure providing equal nitrogen in three out of four comparisons, and did almost as well as sulphate of ammonia providing half as much nitrogen.

Other sections of the report also contain much of interest, for example, those on the farm, and the report on fungus diseases at Rothamsted and at Woburn. Details are given of the experiments at outside centres. It is interesting to observe that in such experiments, which are designed at the Station, the degree of precision compares favourably with that in the experiments carried out at Rothamsted and Woburn.

\title{
ELECTRICITY SUPPLY IN AUSTRALIA AND NEW ZEALAND
}

$\mathrm{T}$ HE rapid expansion in the practical applications of electricity in parts of Australia and New Zealand and the new problems to which it gives rise is well illustrated in the Electrical Times of November 23. In England we consider a 'County Council' as a body which has definite connexions with general public services as, for example, health, education, highways and the like. This is not the case at Sydney, New South Wales, where the 'Sydney County Council' was created in 1935, by a special Gas and Electricity Act, which enables it to assume ownership and control of the electricity department which up to that time had been in the hands of the City Municipal Council. This County Council has only five members, two of them elected by the City Municipal Council and the remaining three being shared by the municipal councils of thirty-two other townships. For election as a councillor, the candidate must be qualified by being eligible for aldermanship in one of these constituencies. This arrangement has points of similarity with that of our own Joint Electricity Authorities (J.E.A.). The Sydney County Council supplies electricity directly to the public in the city, thirty-two suburbs and for street lighting in the city. In addition, it gives a bulk supply to fourteen other municipal authorities who do their own distribution, and to a company which distributes to two other municipal areas. The area throughout which a direct supply is given is about $150 \mathrm{sq}$. miles and its population is about 900,000 . The 'bulk' areas are about 750 square miles and have about 150,000 inhabitants. Altogether the County Council supplies electricity over an area of approximately $900 \mathrm{sq}$. miles and having more than a million inhabitants.

The County Council co-operates with the railway department, which has a supply station of its own so as to level the output and so cheapen the cost. The interchange of energy between them is adjusted so as to be nearly equal at the end of each quarter. The main business of the County Couneil's Electricity Sales Branch is three-fold: first, to develop and advertise the use of electricity in commerce, industry and the home, secondly to sell electrical apparatus and thirdly to deal with contracts for large supplies of energy. The sale of apparatus, ranges, waterheating systems and wash-boilers is arranged for cash or on hire purchase. Instantaneous heaters are sold for cash only. The installation work is also sold by the Council. Two forms of merchandizing are employed. In one the Council buys the equipment and sells it to the consumer. In the other the Council sells the apparatus for the supplier on a commission basis. The basis of the Council's service policy is "make friends with the consumers. This is effected by the advisory service, which not only develops the use of electricity but keeps the consumers satisfied".

Reports from the New Zealand municipalities, which largely utilize hydro-electric power, show that there is considerable anxiety in both North and South Islands as to how to meet the coming winter loads. Deputations have approached the Government and pointed out the limitations of the hydroelectric power available and the urgent need of steamdriven plant to eope with the expected peak load of 1941. The general manager of Christchurch Electricity Department ends his report with these words : "The city of Christchurch is now so completely dependent upon electricity supply in its public services, which include sewerage and water pumping, that the electricity supply intimately concerns hygiene and health as well as the general public life". It looks as if in a few years' time these words would apply to many cities spread over the whole world.

The electrical engineer of Dunedin says that they cannot always count on getting the same ample supply of water-power every year. In severe frosts in winter time very little water-power may be available. The great demand for instantaneous water heaters for baths shifts the maximum load from the afternoon to the early morning. This makes it difficult to devise an equitable multi-tariff meter system which will charge the consumer most at times when the load is a maximum at the supply station. 